\title{
Environmental services in home gardens of la Chontalpa, Tabasco, Mexico
}

\author{
Chablé-Pacual, Rosalva ${ }^{1}$; Palma-Cancino, David J. ${ }^{2}$; Vázquez-Navarrete, Cesar J. ${ }^{1}$; \\ Ruiz-Rosado, Octavio ${ }^{3}$; Mariaca-Méndez, Ramón ${ }^{4}$; Ascensio-Rivera, Jesús ${ }^{5}$; \\ Palma-López, David J. ${ }^{{ }^{*}}$ \\ 1 Colegio de Postgraduados, Campus Tabasco, Cárdenas, Tabasco, México. C. P. 86500. \\ 2 Universidad Popular de la Chontalpa, Cárdenas, Tabasco, México, C.P. 86556 \\ 3 Colegio de Postgraduados, Campus Veracruz, Manlio Fabio Altamirano, Veracruz, México, C. P. 91690. \\ 4 El Colegio de la Frontera Sur, Unidad San Cristóbal, San Cristóbal de las Casas, Chiapas, México, C. P. \\ 29290. \\ 5 Universidad Juárez Autónoma de Tabasco, Centro, Tabasco, México, C. P. 86150. \\ * Correspondence: dapalma@colpos.mx
}

Gitation: Chablé-Pacual, R., PalmaCancino, D. J., Vázquez-Navarrete, C. J., Ruiz-Rosado, O., Mariaca-Méndez, R., Ascensio-Rivera, J., \& Palma-López, D. J.(2021) Environmental services in home gardens of la Chontalpa, Tabasco, Mexico. Agro Productividad. https://doi.org/ 10.32854/agrop. v14i10.204

Editor in Chief: Dr. Jorge Cadena Iñiguez

Received: April 23, 2021. Accepted: September 18, 2021. Published on-line: November 8, 2021

This work is licensed under a Creative Commons Attribution-NonCommercial 4.0 International license.

\section{ABSTRACT}

Objective: To identify the environmental services provided by home gardens in nine communities of La Chontalpa region in Tabasco, Mexico.

Design/methodology/approach: Having previously identified home gardens, a visit route to nine communities was drawn using cartographic and demographic information. Three home gardens per community were randomly selected. Interviews about the use of home gardens were conducted. Physical environmental factors were measured inside and outside the gardens and soil samples were taken to determine organic matter and carbon contents in the soil. According to their category, the environmental services provided by the home gardens in each community were identified and classified into four types: provisioning, supporting, cultural, and regulating services.

Results: Thirteen environmental services were identified as being provided by home gardens. Provisioning and cultural services are present in all localities. The most frequent category is the provision of food, followed by the provision of raw materials and education. Supporting and regulating services were observed in most communities - except for climate regulation, since the environmental conditions only allow gardens to provide the said service in four of the evaluated communities.

Limitations on study/implications: Knowledge about the benefits of building home gardens suggests that these agrosystems provide environmental services. Categorizing the environmental services provided by home gardens is therefore important.

Findings/conclusions: Home gardens in La Chontalpa, Tabasco, do not only provide provisioning services, but also cultural, supporting, and — to a lesser extent - regulating services.

Keywords: Provisioning Services, Supporting Services, Agrosystems, Rural Communities, Welfare.

\section{INTRODUCTION}

The environmental services topic is particularly related to large surface ecosystems and agroecosystems (Ruiz et al., 2007; Palma-López et al., 201 1). Paying for these services has rarely been considered relevant in the case of home gardens $(\mathrm{HG})$. Home gardens are 
considered by definition to be sustainable agroecosystems (Colin et al., 2012; Montañez et al., 2012), since they provide different environmental services, such as: food, raw materials, preservation of local and regional biodiversity, reservoirs of germplasm of both flora and fauna, and soil fertility preservation, among others (Alayón and GurriGarcía, 2009; Sol, 2012).

Home gardens in Tabasco, Mexico, have long achieved transcendence, as a consequence of their worldview (Van der Wal et al., 201 1; Mariaca, 2012), and they maintain their own characteristics. In order to adopt a more global approach for the implementation of home gardens in the tropic, identifying the environmental services that they provide must be the first step. The objective of our research was to highlight the importance of home gardens by identifying and characterizing the different environmental services that these systems provide.

\section{MATERIALS AND METHODS}

The study area was located in the region of La Chontalpa, in the State of Tabasco, Mexico, and included the municipalities of Huimanguillo, Cárdenas, and Comalcalco (Figure 1). The communities were selected based on maps: a transect line was drawn in three representative physiographic zones of the region, focusing on rural communities (INEGI, 2010). Other factors considered were: distance (km), accessibility, and - first and foremost - the localities' availability and willingness to cooperate. Three communities per physiographic zone were chosen and, ultimately, nine localities were studied: Villa Guadalupe, La Soledad, Gustavo Díaz Ordaz, Pedregalito, Tierra Nueva 3ra sección, Miguel Alemán Valdez, El Suspiro, Ignacio Zaragoza, and Ejido G-22 (Lic. José María Pino Suárez). Subsequently, three home gardens per community were chosen and georeferenced (Figure 1).

Soil samples were taken from each intervened home garden at a depth of 0-20 cm, from five randomly selected points. Approximately one kilogram of soil sample was extracted from each sampling point and homogenously mixed in plastic bags to be transferred to the laboratory. Additionally, sunlight incident, environmental temperature, and humidity percentage values were registered within and outside every sampled home garden, in order to obtain an environment control, with the help of a Kestrel 4000 portable weather station.

The dry soil samples were grinded and put through a 2-mm mesh sieve. Afterwards, they were sent to the Laboratorio de Análisis de Suelos, Plantas y Agua (LASPA), where their organic matter, $\mathrm{pH}$, texture, carbon, and bulk density values were determined, based on the methods established by the NOM-021-REGNAT-2000 (DOF, 2002); and those values were later used to estimate the organic carbon sequestration.

Subsequently, with the help of georeferencing, soil analysis and environmental parameters, the environmental services provided by the home gardens of each visited community were identified and - based on the classification proposed by the Millennium Ecosystem Assessment (MEA, 2005) - they were classified according to their function as follows: Provisioning Services, Supporting Services, Cultural Services, and Regulation Services. 


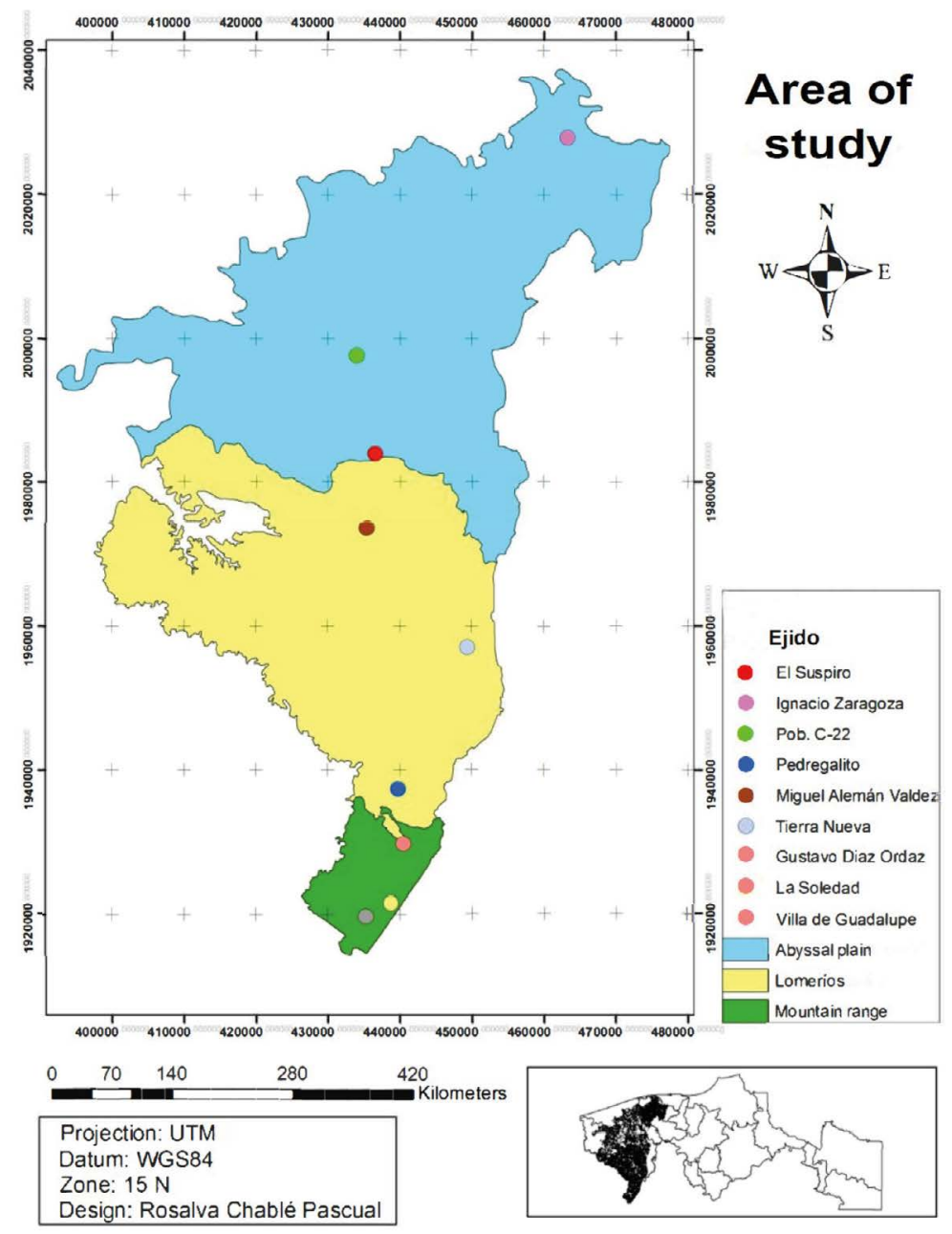

Figure 1. Cartography of the study area and geolocation of intervened communities.

\section{RESULTS AND DISGUSSION}

Physical and demographic factors. The physical environmental factors (i.e., more vegetation) make home gardens ideal places for the comfort of their inhabitants (Mariaca, 2012). The sunlight incident, temperature, and humidity results provide a general picture of how these factors change throughout the day.

Regarding the light, an important decrease of the incident was observed throughout the day within the home gardens, when compared to the surrounding exterior areas. In Villa Guadalupe, for instance, an incident of $1,882 \mu \mathrm{E} \mathrm{m}^{-2} \mathrm{~s}^{-1}$ was recorded outside the gardens (the values increased from 12:00 to $15.00 \mathrm{~h}$ ); during the same period, values of 14-99 $\mu \mathrm{E} \mathrm{m}^{-2} \mathrm{~s}^{-1}$ were recorded inside the gardens (a significantly lower figure). In La Soledad, the light incident outside homes garden reached $2000 \mu \mathrm{E} \mathrm{m}^{-2} \mathrm{~s}^{-1}$ (these values increased after 12:00), while the variation inside the home gardens was lower, reaching a maximum of $260 \mu \mathrm{E} \mathrm{m}^{-2} \mathrm{~s}^{-1}$ between 12:00 and 13:00 h. The lowest sunlight incident values for home gardens were recorded in Gustavo Díaz Ordaz, where the highest value was $89 \mu \mathrm{E} \mathrm{m}^{-2} \mathrm{~s}^{-1}$ (HG1) at noon and the lowest, $14 \mu \mathrm{E} \mathrm{m}^{-2} \mathrm{~s}^{-1}$ (HG3). 
With regard to the environmental temperature within the home gardens, similar values were registered among the assessed communities, where $27.9-29.9{ }^{\circ} \mathrm{C}$ average values were recorded throughout the day - except in Pedregalito, where the recorded average was $34.4^{\circ} \mathrm{C}$ at HG2. The average temperature recorded in all communities were the same inside and around the visited home gardens. The highest temperature points were observed between 13:00 and 16:00 h, with a temperature drop starting from 18:00 h onwards.

The average relative humidity values exceeded $60.8 \%$ and were similar inside and outside the HG. At the Ejido C-22 and Ignacio Zaragoza, the average relative humidity exceeded $85 \%$ in the four sampled zones. The highest values were registered between 02:00 and 06:00 $\mathrm{h}$ and started to drop from 14:00 h onwards in all sampled sites.

Based on the analysis of the environmental data for all home gardens, the light reached its maximum level between 12:00 and 13:00 h, with an average value of $195 \mu \mathrm{E} \mathrm{m}^{-2} \mathrm{~s}^{-1}$. This confirms that the light incident is mitigated in areas with more trees. Temperature and relative humidity remain similar inside and outside the $\mathrm{HG}$, although humidity varies according to the light incident: the higher the light incident, the lower the humidity. Mariaca (2012) states that home gardens protect houses against direct sunshine, cooling the space down and preventing abrupt and excessive temperature and environmental humidity changes. Likewise, Poot-Pool et al. (2012) and Sol (2012) mention that backyard crops bring comfort to the household, since their configuration and structures help regulate the house's temperature, an assumption that could allegedly be extrapolated to the microregion where the crops are located.

In average, home gardens represent $23 \%$ of the village surface. The ratio of home gardens to other ecosystems is highest in the community of Ignacio Zaragoza (29\%) and lowest in La Soledad. The average ejido surface is 1038 ha: the smallest is found in Ignacio Zaragoza (80 ha) and the largest in C-22 (4171 ha). The average village surface is 83 ha, the smallest being El Suspiro and La Soledad with 42 ha. The most populated village is C-22 (INEGI, 2010) (Figure 2a).

Soil analysis. The analysis of carbon $(\mathrm{C})$ and organic matter $(\mathrm{MO})$ in the soil of the sampling areas presented mixed results (Table 1). The highest values were found at the
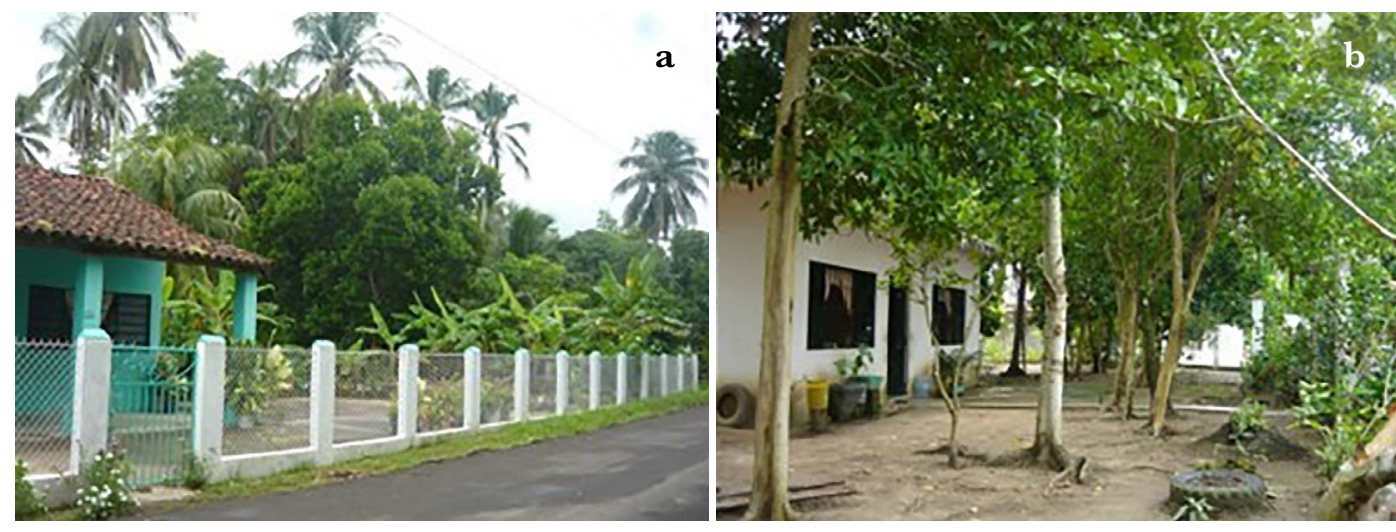

Figure 2. Home gardens in the alluvial plain physiogeographic zone: a. Ejido G-22 (Lic. José María Pino Suárez); b. El Suspiro. 
Table 1. Soil analysis results and sequestered carbon calculation in the visited home gardens.

\begin{tabular}{|c|c|c|c|c|c|c|c|c|}
\hline Ejido & HG & OM (\%) & OC $(\%)$ & BD & Depth $(\mathbf{m})$ & $\mathrm{Kg} \mathrm{C} \mathrm{m}{ }^{2}$ & tha $\mathbf{h}^{-1}$ & $\mathrm{CO}_{2} \mathrm{SEQ}$ \\
\hline \multirow{3}{*}{ Villa Guadalupe } & 1 & 5.9 & 3.0 & 1.2 & 0.2 & 0.7 & 7.1 & 26.0 \\
\hline & 2 & 4.8 & 2.4 & 1.2 & 0.2 & 0.6 & 5.8 & 21.1 \\
\hline & 3 & 4.1 & 2.1 & 1.1 & 0.2 & 0.5 & 4.5 & 16.6 \\
\hline \multirow{3}{*}{ Soledad } & 1 & 6.4 & 3.2 & 1.25 & 0.2 & 0.8 & 8.0 & 29.4 \\
\hline & 2 & 5.1 & 2.6 & 1.25 & 0.2 & 0.6 & 6.4 & 23.4 \\
\hline & 3 & 4.1 & 2.1 & 1.25 & 0.2 & 0.5 & 5.1 & 18.8 \\
\hline \multirow{3}{*}{ Gustavo Díaz Ordaz } & 1 & 2.8 & 1.4 & 1.15 & 0.2 & 0.3 & 3.2 & 11.8 \\
\hline & 2 & 1.5 & 0.8 & 1.25 & 0.2 & 0.2 & 1.9 & 6.9 \\
\hline & 3 & 1.1 & 0.6 & 1.25 & 0.2 & 0.1 & 1.4 & 5.0 \\
\hline \multirow{3}{*}{ Pedregalito } & 1 & 3.8 & 1.9 & 1.2 & 0.2 & 0.5 & 4.6 & 16.7 \\
\hline & 2 & 2.6 & 1.3 & 1.15 & 0.2 & 0.3 & 3.0 & 11.0 \\
\hline & 3 & 1 & 0.5 & 1.15 & 0.2 & 0.1 & 1.2 & 4.2 \\
\hline \multirow{3}{*}{ Tierra Nueva $3^{\text {rd }}$ section } & 1 & 5.6 & 2.8 & 1.25 & 0.2 & 0.7 & 7.0 & 25.7 \\
\hline & 2 & 3 & 1.5 & 1.25 & 0.2 & 0.4 & 3.8 & 13.8 \\
\hline & 3 & 2 & 1.0 & 1.25 & 0.2 & 0.3 & 2.5 & 9.2 \\
\hline \multirow{3}{*}{ Miguel Alemán Valdez } & 1 & 2.8 & 1.4 & 1.25 & 0.2 & 0.4 & 3.5 & 12.8 \\
\hline & 2 & 2 & 1.0 & 1.25 & 0.2 & 0.3 & 2.5 & 9.2 \\
\hline & 3 & 1 & 0.5 & 1.25 & 0.2 & 0.1 & 1.3 & 4.6 \\
\hline \multirow{3}{*}{ El Suspiro } & 1 & 4 & 2.0 & 1.1 & 0.2 & 0.4 & 4.4 & 16.1 \\
\hline & 2 & 2 & 1.0 & 1.1 & 0.2 & 0.2 & 2.2 & 8.1 \\
\hline & 3 & 1.1 & 0.6 & 1.15 & 0.2 & 0.1 & 1.3 & 4.6 \\
\hline \multirow{3}{*}{$\mathrm{C}-22$} & 1 & 3 & 1.5 & 1.1 & 0.2 & 0.3 & 3.3 & 12.1 \\
\hline & 2 & 2.6 & 1.3 & 1.25 & 0.2 & 0.3 & 3.3 & 11.9 \\
\hline & 3 & 1.8 & 0.9 & 1.15 & 0.2 & 0.2 & 2.1 & 7.6 \\
\hline \multirow{3}{*}{ Ignacio Zaragoza } & 1 & 2.3 & 1.2 & 1.25 & 0.2 & 0.3 & 2.9 & 10.6 \\
\hline & 2 & 1.5 & 0.8 & 1.15 & 0.2 & 0.2 & 1.7 & 6.3 \\
\hline & 3 & 1.8 & 0.9 & 1.2 & 0.2 & 0.2 & 2.2 & 7.9 \\
\hline
\end{tabular}

HG: Homegarden; OM: organic matter; OC: organic carbon; BD: bulk density; SEQ: sequestration

Villa Guadalupe and La Soledad communities $(\mathrm{MO}=4.1-6.4 \% ; \mathrm{C}=2.1-3.2 \%)$, while the Miguel Alemán Valdez and Ignacio Zaragoza villages presented the lowest figures $(\mathrm{MO}=$ $1-2.8 \% ; \mathrm{C}=0.5-1.2 \%)$.

Potential carbon sequestration values are not high in home gardens $\left(<10 \mathrm{t} \mathrm{ha}^{-1}\right)$; however, the said values are considerable for environmental services payment (ESP) benefits (Hernández et al., 2016). The low $\mathrm{C}$ content in the soil might be the result of constant cleaning at home gardens (Cotler et al., 2016). The low MO contents in the soil might be the result of the high use of nutrients made by cultivated plants and of the tendency of MO to oxidize — which releases nutrients (Rimski-Korsakov and Álvarez, 2016).

Identification and characterization of environmental services. Cultural services (CS) were identified in all gardens of the visited communities (Table 2). SC quantification is 
Table 2. Identification of environmental services per type in every assessed community according to MEA (2005).

\begin{tabular}{|c|c|c|c|c|c|c|c|c|c|c|c|c|c|}
\hline \multirow{2}{*}{ Community } & \multicolumn{3}{|c|}{ PS } & \multicolumn{4}{|c|}{ SS } & \multicolumn{2}{|c|}{ CS } & \multicolumn{4}{|c|}{$\mathbf{R S}$} \\
\hline & 1 & 2 & 3 & 4 & 5 & 6 & 7 & 8 & 9 & 10 & 11 & 12 & 13 \\
\hline Villa Guadalupe & $\mathrm{X}$ & $\mathrm{X}$ & $\mathrm{X}$ & $\mathrm{X}$ & $\mathrm{X}$ & $\mathrm{X}$ & & $\mathrm{X}$ & $\mathrm{X}$ & $\mathrm{X}$ & & $\mathrm{X}$ & $\mathrm{X}$ \\
\hline La Soledad & $\mathrm{X}$ & $\mathrm{X}$ & $\mathrm{X}$ & $\mathrm{X}$ & $\mathrm{X}$ & $\mathrm{X}$ & & $\mathrm{X}$ & $\mathrm{X}$ & $\mathrm{X}$ & & $\mathrm{X}$ & $\mathrm{X}$ \\
\hline Gustavo Díaz Ordaz & $\mathrm{X}$ & $\mathrm{X}$ & & $\mathrm{X}$ & $\mathrm{X}$ & $\mathrm{X}$ & & $\mathrm{X}$ & $\mathrm{X}$ & $\mathrm{X}$ & & $\mathrm{X}$ & $\mathrm{X}$ \\
\hline Pedregalito & $\mathrm{X}$ & $\mathrm{X}$ & & $\mathrm{X}$ & $\mathrm{X}$ & $\mathrm{X}$ & $\mathrm{X}$ & $\mathrm{X}$ & $\mathrm{X}$ & $\mathrm{X}$ & $\mathrm{X}$ & $\mathrm{X}$ & $\mathrm{X}$ \\
\hline Tierra Nueva $3^{\text {rd }}$ section & $\mathrm{X}$ & $\mathrm{X}$ & & $\mathrm{X}$ & $\mathrm{X}$ & $\mathrm{X}$ & $\mathrm{X}$ & $\mathrm{X}$ & $\mathrm{X}$ & $\mathrm{X}$ & $\mathrm{X}$ & $\mathrm{X}$ & $\mathrm{X}$ \\
\hline Miguel Alemán Valdez & $\mathrm{X}$ & $\mathrm{X}$ & $\mathrm{X}$ & $\mathrm{X}$ & $\mathrm{X}$ & $\mathrm{X}$ & $\mathrm{X}$ & $\mathrm{X}$ & $\mathrm{X}$ & $\mathrm{X}$ & $\mathrm{X}$ & $\mathrm{X}$ & $\mathrm{X}$ \\
\hline El suspiro & $\mathrm{X}$ & $\mathrm{X}$ & & $\mathrm{X}$ & $\mathrm{X}$ & $\mathrm{X}$ & $\mathrm{X}$ & $\mathrm{X}$ & $\mathrm{X}$ & $\mathrm{X}$ & $\mathrm{X}$ & $\mathrm{X}$ & $\mathrm{X}$ \\
\hline G-22 & $\mathrm{X}$ & $\mathrm{X}$ & & $\mathrm{X}$ & $\mathrm{X}$ & $\mathrm{X}$ & & $\mathrm{X}$ & $\mathrm{X}$ & $\mathrm{X}$ & & $\mathrm{X}$ & $\mathrm{X}$ \\
\hline Ignacio Zaragoza & $\mathrm{X}$ & $\mathrm{X}$ & $\mathrm{X}$ & $\mathrm{X}$ & $\mathrm{X}$ & $\mathrm{X}$ & $\mathrm{X}$ & $\mathrm{X}$ & $\mathrm{X}$ & $\mathrm{X}$ & & $\mathrm{X}$ & $\mathrm{X}$ \\
\hline
\end{tabular}

PS: Provisioning services, SS: Supporting services, CS: Cultural services, RS: Regulating services. 1: Food, 2: Raw materials, 3: Genetic material, 4: Soil formation, 5: Pollination, 6: Biological control, 7: Home, 8: Education, 9: Culture, 10: Gas regulation, 11: Weather regulation, 12: Erosion mitigation, 13: Nutrient cycle regulation.

more subjective (De Groot et al., 2010), but those services are easier to identify (Rodríguez et al., 2016; Merlotto and Verón, 2019). In the case of home gardens, educational CS are very important, because knowledge about crop development can be taught to family members from an early age, thus generating cultural growth among households (PalmaLópez et al., 201 1; Mariaca, 2012).

Food and raw materials were identified among the provisioning services (PS) in all communities. This matches the findings of Palma-López et al. (2011), who emphasize that, with regard to their own concept, home gardens offer these kinds of ecosystemic services to each household where they are implemented. Genetic material PS were only found in Villa Guadalupe, La Soledad, Miguel Alemán Valdez, and Ignacio Zaragoza, probably as a result of the greater plant diversity of these communities' gardens.

Supporting (SS) and regulating services (RS) were identified in almost every HG of the communities. However, the capacity to provide habitat SS and climate RS was only observed at the communities of Pedregalito, Tierra Nueva 3ra Sección, Miguel Alemán Valdez, and El Suspiro (Figure 2b). Environmental conditions for these services within HG were only found in the aforementioned communities, primarily as a result of the stability of the said conditions and a greater difference compared to the conditions outside the HG. Miguel Alemán Valdez and El Suspiro are very likely to benefit from the environmental services payment (ESP) program, just as was pointed out by Palma-López et al. (2011) and Chablé-Pascual et al. (2015).

The environmental conditions of home gardens generate many benefits for households (Mariaca, 2012; Poot-Pool et al., 2012). In this respect, environmental services are an important alternative for the inhabitants of the visited communities (Colin et al., 2012). The economy of most of the households in the sampling communities that own HG depends on primary production activities (Chablé-Pascual et al., 2015). These gardens increase the 
households' comfort, not only with the on-farm consumption of its produce, but also with socioeconomically and environmentally healthier surroundings.

The most important environmental service present in the sampled HG was food provisioning. Alayón and Gurri-García (2009), Sol (2012), and Vázquez et al. (2012) state that species used as food are key resources in the $\mathrm{HG}$, since they have a positive impact on the household diet and nutrition. Juan (2013) reports that the use of produce obtained from $\mathrm{HG}$ is very important in the household diet and that $63 \%$ of the said produce is cooked by the owners of the HG.

The raw materials provisioning service is essential in the sampled HG, whose owners mentioned the use of resources such as composts for other crops, natural or herbal medicine, fodder, and handmade products such as jams and spicy sauces. Pérez et al. (2012) and Sol (2012) mention that one social function of the HG is satisfying the inhabitants' needs, not only with food, but also with raw materials for fuel and construction, as well as fodder for the farm animals that live within the garden. Guzmán et al. (2012) report that, in the HG of Olcuatitán, Nacajuca, Tabasco, only 35\% of garden products are used as food; the use of raw materials for other purposes is more important. Those purposes include: non-timber products (13\%), construction (7\%), medicine (29\%), fuel (85\%) and others (16\%).

\section{CONGLUSIONS}

Promoting the implementation of home gardens and extending the value chains derived from these sustainable agrosystems is beneficial for the life quality of the inhabitants of the rural communities of La Chontalpa, Tabasco, Mexico. Home gardens provide several environmental services in the visited communities —although provisioning and cultural services stand out. We recommend transferring the knowledge about environmental services in home gardens, in order to increase the commitment of the owners of these systems to maintain and diversify the products they offer.

\section{REFERENGES}

Alayón, G.J.A., \& Gurri-García, F.D. (2009). Home garden production and energetic sustainability in Calakmul, Campeche, México. Human Ecology 37: 55-77.

Chablé-Pascual, R., Palma-López, D.J., Vázquez-Navarrete, C.J., Ruiz-Rosado, O., Mariaca-Méndez, R., \& Ascensio-Rivera, J.M. (2015). Estructura, diversidad y uso de las especies en huertos familiares de la Chontalpa, Tabasco, México. Ecosistemas y Recursos Agropecuarios, 2(4): 23-39.

Colin, H., Hernández, C.A., \& Monroy, R. (2012). El manejo tradicional y agroecológico en un huerto familiar de México, como ejemplo de sostenibilidad. Etnobiología, 10: 12-28.

Cotler, H., Martínez, M., \& Etchevers, J.D. (2016). Carbono orgánico en suelos agrícolas de México: investigación y políticas públicas. Terra Latinoamericana, 34(1): 125-138.

De Groot, R., Alkemade, R., Braat, L., Hein, L., \& Willemen, L. (2010). Challenges in integrating the concept of ecosystem services and values in landscape planning, management and decision making. Ecological Complexity, 7: 260-272.

Diario Oficial de la Federación (DOF) (2002). NOM-021-REGNAT 2000. Que establece las especificaciones de fertilidad, salinidad y clasificación de suelos. Estudios, muestreo y análisis. Ciudad de México: Secretaría de Medio Ambiente y Recursos Naturales.

Guzmán, S.G., López, H.E.S., \& Gisper, C.M. (2012). Huertos familiares y estrategias de educación ambiental con chontales de Olcuatitán, Nacajuca, Tabasco. En: Mariaca, M.R. (ed), El Huerto familiar del sureste de México. San Cristóbal de las Casas: El Colegio de la Frontera Sur, SERNAPAM: 460-485 p. 
Hernández, M.G.I., Sol-Sánchez, A., Ruiz-Rosado, O., \& Valdez-Hernández, J.I. (2016). Controversias legislativas en la protección del ecosistema manglar: el caso Tabasco, México. Revista Mexicana de Ciencias Agrícolas, 14: 2841-2855.

INEGI (Instituto Nacional de Estadística y Geografía) (2010). Censo de población y vivienda 2010. Ciudad de México: INEGI.

Juan, P.J.I. (2013). Los huertos familiares en una provincia del subtrópico mexicano: análisis espacial, económico y sociocultural. Toluca: Universidad Autónoma del Estado de México.

Merlotto, A., \& Verón, E.M. (2019). Evaluación de los servicios culturales de recreación y turismo del ecosistema playa, en la ciudad de Mar de la Plata, Argentina. Revista Universitaria de Geografía, 28(2): 35-49.

Mariaca, M.R. (2012). La complejidad del huerto familiar Maya del sureste de México. En: Mariaca, M.R. (ed), El Huerto familiar del sureste de México. San Cristóbal de las Casas: El Colegio de la Frontera Sur, SERNAPAM: 7-97 p.

MEA (Millennium Ecosystem Assessment). (2005). Ecosystems and human well-being: a framework for assessment. Washington, D.C.: United Nations, Island Press.

Montañez, E.P.I., Ruenes, M.M.R., Jiménez, O.J.J., Chimal, G.P., \& López, B.L. (2012). Los huertos familiares o solares en Yucatán. En: Mariaca, M.R. (ed), El Huerto familiar del sureste de México. San Cristóbal de las Casas: El Colegio de la Frontera Sur, SERNAPAM: 131-147 p.

Palma-López, D.J., Vázquez-Navarrete, C.J., Mata-Zayas, E.E., López-Castañeda, A., Morales-Garduza, M.A., Chablé-Pascual, R., Contreras, H.J., \& Palma-Cancino, D.Y. (2011). Zonificación de ecosistemas y agroecosistemas susceptibles de recibir pagos por servicios ambientales en La Chontalpa, Tabasco. Villahermosa: Colegio de Postgraduados Campus Tabasco, SERNAPAM.

Pérez, V.A., Guanalo, C.H., \& Sol, S.A. (2012). Los huertos familiares perspectivas de investigación y contribución al desarrollo sustentable. En: Mariaca, M.R. (ed), El Huerto familiar del sureste de México. San Cristóbal de las Casas: El Colegio de la Frontera Sur, SERNAPAM: 420-433 p.

Poot-Pool, W.S., Van der Wal, H., Flores-Guido, S., Pat-Fernández, J.M., \& Esparza-Olguín, L.G. (2012). Economic stratification differentiates home gardens in the Maya village of Pomuch, Mexico. Economic Botany, 66: 264-275. DOI: http://dx.doi.org/10.1007/s12231-015-9313-z

Rimski-Korsakov, H., \& Álvarez, C.R. (2016). Materia orgánica del suelo. En: Álvarez, C.R., Rimski-Korsakov, H. (eds), Manejo de la fertilidad del suelo en planteos orgánicos, Buenos Aires: Editorial Facultad de Agronomía-Universidad de Buenos Aires: 59-69 p.

Rodríguez, G.L., Guretti, G., Garegnani, G., Grilli, G., Pastorella, F., \& Paletto, A. (2016). La valoración de los servicios ecosistémicos en los ecosistemas forestales: un caso de estudio en Los Alpes Italianos. Bosque, 37(1): 41-52. DOI: https://doi.org/10.4067/S0717-92002016000100005

Ruiz, P.M., García, F.C., \& Sayer, J.A. (2007). Los servicios ambientales de los bosques. Ecosistemas: Revista Científica y Técnica de Ecología y Medio Ambiente 16(3): 80-89.

Sol, S.A. (2012). El papel económico de los huertos familiares y su importancia en la conservación de especies y variedades locales. En: Mariaca, M.R. (ed), El Huerto familiar del sureste de México. San Cristobal de las Casas: El Colegio de la Frontera Sur, SENAPAM: 361-370 p.

Van der Wal, H., Huerta, L.E., \& Torres, D.A. (2011). Huertos familiares en Tabasco: elementos para una politica integral en materia de ambiente, biodiversidad, alimentación, salud, producción y economía. Villahermosa: Gobierno del Estado de Tabasco, SERNAPAM, El Colegio de la Frontera Sur. 